\title{
Fish processing work: the impact of two sex dependent exposure profiles on musculoskeletal health
}

Catarina Nordander, Kerstina Ohlsson, Istvan Balogh, Lars Rylander, Birgitta Pålsson, Staffan Skerfving

\begin{abstract}
Objectives-To evaluate the impact of work tasks, physical exposure, and psychosocial factors on the risk of musculoskeletal disorders in men and women, in a defined industrial setting.

Methods-116 male and 206 female fish industry workers were compared with 129 men and 208 women with more varied work. Physical and psychosocial work load as well as musculoskeletal complaints were recorded by a questionnaire. A physical examination was performed and an observation method was used for work evaluation. 196 male and 322 female former fish processing workers received a postal questionnaire.
\end{abstract}

Results-The women workers in the fish industry had worse working conditions than the men for repetitiveness, constrained neck postures, and psychosocial work environment. They also had higher prevalences of complaints of the neck and shoulder (prevalence odds ratio (POR) 1.9; $95 \%$ confidence interval $(95 \%$ CI $) 1.1$ to 3.2), neck and shoulder and elbow and hand complaints (POR 2.9; 95\% CI 1.8 to 4.7 and POR $2.8 ; 95 \%$ CI 1.6 to 4.7 , respectively). The women more often than the men left the industry because of neck and upper limb complaints. Also, women in other work had a higher prevalence of complaints of the neck and shoulder (POR $2.3 ; 95 \%$ CI 1.1 to 5.1 ) than the men. The men in the fish processing industry had a higher prevalence of complaints of the neck and shoulder than the men in other work (POR 3.6; 95\% CI 1.6 to 8.0 ). This difference was not shown up by the questionnaire.

Conclusions-Despite superficially similar work, there were clear sex differences in physical exposure and psychosocial work environment. Work in the fish processing industry was associated with a high risk of neck and upper limb disorders in women, which was probably mainly due to their extremely repetitive work tasks; the corresponding men had less repetitive work and less disorders. Also, a healthy worker effect on neck and upper limb disorders was found. The advantage of a physical examination compared with a questionnaire is clearly shown.

(Occup Environ Med 1999;56:256-264)

Keywords: sex; work environment; musculoskeletal system
Disorders of the musculoskeletal system constitute a considerable health problem in industrialised societies. Much interest has been paid to low back pain, ${ }^{1}$ a disorder which particularly affects men. On the contrary, neck and upper limb disorders, which also imply a considerable health problem, are more common among women. ${ }^{2}$ The explanation for this sex difference is not clear.

The differences might be due to varying physical working conditions (heavy lifting and awkward postures in men versus repetitive work in women). ${ }^{3-6}$ Thus, construction work, which is a typical male occupation, is associated with low back problems. ${ }^{78}$ Further, in certain jobs-for example, the fish processing industry-where the problem of neck and shoulder disorders is particularly evident, ${ }^{29}$ there is a predominance of women in the workforce. However, under equal working conditions, there might not be a difference in prevalence of musculoskeletal disorders between the sexes. Indeed, the limited data to hand indicate that this is the case. ${ }^{10}$ Conversely, this aspect of the working environment has seldom been systematically evaluated. ${ }^{11} 12$

Psychosocial factors have also been discussed as risk factors for musculoskeletal disorders. ${ }^{13}{ }^{14}$ However, there is no consistent evidence for a causal relation. The amount of household work and leisure time activities might also vary between sexes, which could be one of the reasons for the difference in the distribution of disorders. Another possibility is differences in susceptibility between the sexes - for instance, due to differences in muscular strength and endurance. There is a need for more knowledge about which variables explain the sex difference.

The aim of this study was to measure the risk of musculoskeletal disorders among fish processing workers, and to compare men and women workers, all employed in fish processing plants, and supposedly performing identical work. Moreover, our intention was to study the impact on these disorders of physical and psychosocial factors in the work environment, along with personal factors and leisure time activities.

\section{Subjects and methods}

The study comprised all 13 fish processing plants on the south east coast of Sweden, located in four different towns. The industries had between 10 and 55 employees. Also, a referent group consisting of men and women, with varied and mobile work tasks, was studied. 
Some of the results on the women workers and other subjects have been published elsewhere. ${ }^{5}$

SUBJECTS

Fish processing workers

Men-There were 116 men employed. Their mean age was 41 (range 19-65) years at the time of the study, and their mean duration of employment was 9.2 (range 0.2-39) years. This group comprised eight men on long term (>1 month) sick leave (mean age 45 (range 19-60) years; mean duration of employment 12 (range 0.6-26) years); all but two because of musculoskeletal disorders, according to physicians' certificates.

Eight men were on leave-for example, study leave or on military service - and 17 $(15 \%)$ refused to participate, so they were not included.

A group of 196 former male workers, who had left employment during the 10 years before the study (mean age 36 (range 20-74) years; mean duration of employment 5.0 (range 0.2 51) years) received a postal questionnaire.

Women-There were 206 women employed. Their mean age was 39 (range 17-64) years at the time of the study, and their mean duration of employment 6.3 (range 0.2-17) years. This group included 34 women on long term sick leave (mean age 44 (range 18-64) years; mean duration of employment 9.5 (range 1.7-25) years). Their mean time on sick leave was 15 (range 1- 51) months. All but three were on sick leave because of musculoskeletal disorders.

At the time of the study, 24 women were on maternity leave or study leave and 17 women $(8 \%)$ refused to participate. These were not included.

A group of 322 female former workers, who had left their employment in the fish processing industry during the 10 years before the study (mean age 36 (range 17-73) years; mean duration of employment 4.3 (range $0.2-43$ ) years) received a postal questionnaire.

The response rate among the former workers (men and women combined) was $55 \%$. It varied between $35 \%$ and $100 \%$ among the different industries.

Other workers

Men-The referent group included 129 men (mean age 44 (range 20-65) years; mean duration of employment 13 (range 0.8-40) years) from the same towns as the exposed group. These men had work tasks which were varied and were neither very heavy nor repetitive. They were employed as caretakers, they worked in community parks and gardens, and some worked at repairing and maintaining equipment and machines in the community. This group included three men on long term sick leave, one due to musculoskeletal disorders. Their mean age was 50 (range 37-59) years, and their mean duration of employment was 14 (range $2-23$ ) years. Three men were on leave, two $(1.5 \%)$ refused to participate, and were thus excluded.

Women - The referent group included all 208 women (mean age 40 (range 17-64) years; mean duration of employment 10 (range 0.2-35) years) employed in 12 municipal workplaces in the same towns as the exposed group. Their work tasks were varied and mobile. They were employed in day nurseries, they worked in offices with various work tasks (no constant visual display unit work or typing), they took care of elderly people and some were gardeners. Two of these 208 women were on sick leave, one of these due to musculoskeletal disorders.

\section{Methods}

STUDY DESIGN

The study was cross sectional (a one time survey). Interviews and physical examinations were carried out at the worksites of the currently employed subjects (fish processing workers and others). Several visits were paid to each of the fish processing factories to evaluate the work environment and work load.

Former fish processing workers had a brief questionnaire sent to them, including questions about duration of employment, type of work tasks, musculoskeletal complaints during their employment, and their reasons for leaving.

\section{Assessment of musculoskeletal disorders}

Questionnaire-Subjective complaints in the neck and upper limbs during the past 12 months and past 7 days, as well as inability to work during the past 12 months, were recorded in an interview based on a questionnaire. ${ }^{15}$

Physical examination-Immediately after the interview, a standardised examination was made of the neck, shoulders, elbows, and hands $^{16}$ of all currently employed workers. Symptoms and signs were recorded by the same examiner for all the men, and by another examiner for all the women, including those on sick leave. No physical examination was performed on the former workers.

The examiners decided diagnoses, based on a standard set of criteria, from symptoms, as well as signs. ${ }^{16}$ A prerequisite of all complaints was that the subject reported pain before provocation and palpation of the tissues. Each person could have more than one complaint.

\section{Work environment assessment}

Questionnaire-Duration of present employment, as well as former employment in repetitive and in physically heavy work was recorded. For each person, the time distribution of the work tasks was recorded to enable a systematic evaluation. Total weight of materials handled in a day was registered. Also, a method designed for a systematic evaluation of psychosocial work environment was used. ${ }^{17}$ This included the following five areas: influence on and control over work, relations with the supervisor, stimulus from the work itself, relations with fellow workers, and physical and psychological work load. For each area five related questions were asked, and the answers were rated from $1=$ low to $5=$ high .

Ergonomic workplace analysis - The observation method, ergonomic workplace analysis, ${ }^{18}$ based on the method AET (Arbeitswissenschaftliche Erhebungsverfahren zur 
Tätigkeitsanalyse $)^{19}$ and the guidelines for lifting of the United States National Institute of Occupational Safety and Health (NIOSH), ${ }^{20}$ was used in the fish processing industries. This has been designed by the Finnish Institute of Occupational Health. It aims at a systematic description of a task or a workplace, to identify ergonomic problems. It can be used, for example, in an intervention study to compare a work task before and after an alteration. The experience of the method in epidemiological studies is limited. We analysed the following 10 items: work site, general physical activity, lifting, work postures and movements, job content, job restrictiveness, worker communication, difficulty of decision making, repetitiveness of the work, and attentiveness. Each item was rated on a scale, usually 1-5. A rating of 1 implies low strain conditions, whereas a rating of 4-5 indicates that the working conditions or environment could be harmful to the workers' health. ${ }^{18}$ For the other workers, no observations of the work environment were made.

Videotape recordings-All work tasks were videotaped to help memory and the classification (see later).

Exposure profile-Based on the observations of the ergonomic workplace analysis, questionnaire, and videotape recordings, each work task was classified according to three factors: weight of the materials handled $(<1,1-<5,5-<10$, $10-<25, \geqslant 25 \mathrm{~kg})$, cycle time $(<5,5-<10$, $10-<60, \geqslant 60 \mathrm{~s})$, and degree of constrained neck postures (low, high, very high). Thus, 60 possible physical work load cells were obtained. One subject often had several work tasks. For every currently exposed person (including those on long term sick leave), the proportion of time spent performing work in each work load cell was calculated. The total amount of working time performed in each work load cell, by all women and all men, respectively, was calculated and expressed as a percentage of all working time performed by each sex group.

\section{Individual factors}

The questionnaire included the following individual factors.

Liability to develop subjective stress and worry, both during and outside work (tendency towards stress and worry) was assessed. ${ }^{5}$ This was calculated as the mean score over five related questions, each ranging on an ordinal scale from 1 (low) to 4 (high). The subjects were exposed to the following statements: I easily develop feelings of worry; restlessness; nervousness; rush; or emotional tension. Each subject rated how well this applied to him or her. A rating of 4 implied that the statement was highly accurate, whereas a rating of 1 meant definitely not accurate for him or her.

A method earlier used for systematic evaluations of subjective tendency towards muscular tension was used. This was assessed as the number of a series of experienced habits (Do you often: Hold your breath? Contract your stomach muscles? Keep your breath high? Sit on the edge of your chair? Contract your neck muscles? Raise your shoulders? Contract your chewing muscles? Grind your teeth? Hold tools unnecessarily hard? Squint? Frown?). ${ }^{21}$ The answer no was rated 0 , sometimes was rated 0.5 , and yes was rated 1 . The sum for each person was calculated, giving a minimum of 0 and a maximum of 11 points, 11 being a very high tendency towards subjective muscular tension.

One of the dimensions of social networknamely, contact frequency-was also assessed by seven questions. This included relations with foremen and fellow workers. ${ }^{22}$ The mean score over the questions, each ranging from 1 (seldom or never) to 5 (daily), was calculated. Separate scores were obtained for the social networks at and outside work.

The number of cigarettes currently smoked a day was registered.

Leisure time activities were assessed by questions about different kinds of handicraft (which included knitting, weaving, and machine sewing), gardening and repairs (including house and car repairs), sports (including jogging, racket games, team sports, gymnastics, and weight lifting), and fishing or hunting. The subjects were asked how often each activity occurred, and activities performed at least once a week were considered regular habits.

\section{STATISTICS}

The prevalence odds ratio (POR) was used as the effect measure. A POR reflects the impact of exposure on prevalence of a disorder. Under certain assumptions, and if the duration of disease in the exposed and control groups is equal, the POR in a cross sectional study will estimate the incidence rate ratio. ${ }^{23-25}$ The statistical package for the social sciences (SPSS, Chicago, IL, USA) was used for standard statistical analyses, and to calculate the age adjusted PORs, and corresponding confidence intervals ( $95 \%$ CIs), by using the logistic regression model. For statistical testing of group differences, the Mann-Whitney $U$ test was used. Effects of age, smoking, and leisure time activities on complaints were assessed by logistic regression. Two times contingency tables were tested by Fisher's exact test. Significance was at the $\mathrm{p}<0.05$ (two tailed) level.

\section{Results}

MUSCULOSKELETAL DISORDERS

Complaints

Among the fish processing workers, the women had prevalences of neck, shoulder, elbow, and hand complaints almost three times higher than the men (table 1). For other body regions, there were no significant differences.

The prevalences of subjective complaints were considerably higher among the women fish processing workers than among other women workers, for all regions except the hips (table 1). The difference was most pronounced for the neck and upper limbs. On the contrary, for the men, hardly any difference was shown for any body region.

Among the subjects with other work, there were no significant sex differences for neck, shoulders, elbows, and hands, but the prevalence of low back and knee complaints was significantly lower in women than in men (table 1). 
Table 1 Prevalences of complaints(during the past 7 days) and diagnoses in different anatomical regions in 116 male and 206 female workers, presently employed in the fish processing industry, as well as in 129 male and 208 female workers with other work (age and sex adjusted prevalence odds ratios (POR) with $95 \%$ CI)

\begin{tabular}{|c|c|c|c|c|c|c|c|c|c|}
\hline & \multicolumn{3}{|c|}{ Fish processing workers } & \multicolumn{3}{|c|}{ Other workers } & \multicolumn{3}{|c|}{ Fish processing workers $v$ other workers } \\
\hline & $\begin{array}{l}M e n \\
n=116\end{array}$ & $\begin{array}{l}\text { Women } \\
n=206\end{array}$ & & $\begin{array}{l}M e n \\
n=129\end{array}$ & $\begin{array}{l}\text { Women } \\
n=208\end{array}$ & & Men & Women & All \\
\hline & $\begin{array}{l}n \\
(\%)\end{array}$ & $\begin{array}{l}n \\
(\%)\end{array}$ & $\begin{array}{l}\text { POR } \\
(95 \% \text { CI) }\end{array}$ & $\begin{array}{l}n \\
(\%)\end{array}$ & $\begin{array}{l}n \\
(\%)\end{array}$ & $\begin{array}{l}\text { POR } \\
(95 \% \text { CI) }\end{array}$ & $\begin{array}{l}\text { POR } \\
(95 \% C I)\end{array}$ & $\begin{array}{l}\text { POR } \\
(95 \% \text { CI) }\end{array}$ & $\begin{array}{l}\text { POR } \\
(95 \% \text { CI) }\end{array}$ \\
\hline \multicolumn{10}{|l|}{ Complaints: } \\
\hline Neck and shoulders & $37(32)$ & $114(55)$ & $2.9(1.8$ to 4.7$)$ & $37(29)$ & $68(33)$ & $1.5(0.9$ to 2.4$)$ & $1.3(0.7$ to 2.3$)$ & $2.6(1.7$ to 3.8$)$ & $2.1(1.5$ to 2.9$)$ \\
\hline Elbows and hands & $28(24)$ & $91(44)$ & $2.8(1.6$ to 4.7$)$ & $27(21)$ & $34(16)$ & $0.9(0.5$ to 1.6$)$ & $1.2(0.7$ to 2.2$)$ & $4.0(2.6$ to 6.4$)$ & $2.9(2.0$ to 4.2$)$ \\
\hline Lower back & $31(27)$ & $60(29)$ & $1.1(0.7$ to 1.9$)$ & $42(33)$ & $31(15)$ & $0.4(0.2$ to 0.7$)$ & $0.8(0.4$ to 1.3$)$ & $2.4(1.4$ to 3.9$)$ & $1.5(1.0$ to 2.1$)$ \\
\hline Hip & $11(10)$ & $22(11)$ & $1.3(0.6$ to 2.9$)$ & $20(15)$ & $18(9)$ & $0.6(0.3$ to 1.2$)$ & $0.6(0.3$ to 1.3$)$ & $1.3(0.7$ to 2.5$)$ & $0.9(0.6$ to 1.5$)$ \\
\hline Knee & $22(19)$ & $35(17)$ & $0.9(0.5$ to 1.6$)$ & $29(22)$ & $14(7)$ & $0.3(0.1$ to 0.6$)$ & $0.9(0.5$ to 1.6$)$ & $2.9(1.4$ to 6.1$)$ & $1.6(1.0$ to 2.5$)$ \\
\hline Foot and ankle & $9(8)$ & $20(14)$ & $1.9(0.9$ to 4.2$)$ & $15(12)$ & $11(5)$ & $0.5(0.2$ to 1.2$)$ & $0.7(0.3$ to 1.7$)$ & $2.6(1.8$ to 4.0$)$ & $1.6(1.0$ to 2.8$)$ \\
\hline \multicolumn{10}{|l|}{ Diagnoses: } \\
\hline Neck and shoulders & $26(22)$ & $71(34)$ & $1.9(1.1$ to 3.2$)$ & $10(8)$ & $29(14)$ & $2.3(1.1$ to 5.1$)$ & $3.6(1.6$ to 8.0$)$ & $3.2(2.0$ to 5.3$)$ & $3.5(2.3$ to 5.3$)$ \\
\hline Elbows and hands & $7(6)$ & $20(10)$ & $1.8(0.7$ to 4.5$)$ & $2(2)$ & $7(3)$ & $2.7(0.5$ to 13$)$ & $4.3(0.9$ to 21$)$ & $3.1(1.3$ to 7.5$)$ & $3.5(1.6$ to 7.7$)$ \\
\hline
\end{tabular}

Table 2. Clinical diagnoses from 206 women and 116 men, currently employed in the fish processing industries, and 208 women and 129 men with other work

\begin{tabular}{lccccc}
\hline & \multicolumn{2}{c}{ Women } & & Men & \\
\cline { 2 - 3 } \cline { 5 - 6 } Diagnosis & $\begin{array}{l}\text { Exposed } \\
n(\%)\end{array}$ & $\begin{array}{l}\text { Control } \\
n(\%)\end{array}$ & & $\begin{array}{l}\text { Exposed } \\
n(\%)\end{array}$ & $\begin{array}{l}\text { Control } \\
n(\%)\end{array}$ \\
\hline Tension neck & $39(19)$ & $15(7)$ & & $11(10)$ & $5(4)$ \\
Cervical syndrome & $11(5)$ & $0(0)$ & & $0(0)$ & $1(1)$ \\
Thoracic outlet syndrome & $6(3)$ & $3(1)$ & & $0(0)$ & $0(0)$ \\
Frozen shoulder & $4(2)$ & $1(0.5)$ & & $0(0)$ & $0(0)$ \\
Supraspinatus tendinitis & $30(15)$ & $10(5)$ & & $3(3)$ & $1(1)$ \\
Infraspinatus tendinitis & $25(12)$ & $6(3)$ & & $3(3)$ & $1(1)$ \\
Bicipital tendinitis & $20(10)$ & $9(4)$ & & $5(4)$ & $3(2)$ \\
Acromioclavicular syndrome & $35(17)$ & $13(6)$ & & $8(7)$ & $0(0)$ \\
Lateral or medial epicondylitis & $7(4)$ & $6(3)$ & & $7(6)$ & $2(2)$ \\
Pronator teres syndrome & $0(0)$ & $1(0.5)$ & & $0(0)$ & $0(0)$ \\
Radial tunnel syndrome & $0(0)$ & $0(0)$ & & $0(0)$ & $0(0)$ \\
Peritendinitis or tenosynovitis of the wrist & $5(2)$ & $0(0)$ & & $0(0)$ & $0(0)$ \\
Carpal tunnel syndrome & $5(2)$ & $1(0.5)$ & & $0(0)$ & $0(0)$ \\
Ulnar nerve entrapment (at the wrist or elbow) & $0(0)$ & $0(0)$ & & $0(0)$ & $0(0)$ \\
\hline
\end{tabular}

Diagnoses

The most common complaints were tension of the neck, acromioclavicular syndrome, and rotator cuff tendinitis (table 2).

The women in the fish processing group, as well as in the other group, had twice as high a prevalence of complaints of the neck and shoulder as the men (table 1 ).

The women in the fish processing industries had much higher prevalences of complaints in the neck, shoulders, elbows, and hands than the women with other work (table 1).

In men in the different occupational groups great differences for neck, shoulder, elbow, and hand complaints were registered. Four times as many complaints were recorded among the men in the fish processing industries in both regions.
PHYSICAL EXPOSURE IN WORK TASKS IN THE FISH PROCESSING INDUSTRY

The amounts of fresh fish varied, which resulted in many changes between work tasks. The six most common work tasks (covering $97 \%$ of the total working time) were:

(1) Work at the cod filleting machines, which removed the cods' heads, skin, and most of the bones. The fish were mounted in the machine one by one, work was performed standing, and with extremely rapid cycles, as short as $2 \mathrm{~s}$ (not in table). In the ergonomic workplace analysis, this task received maximum scores for general physical activity, work postures and movements, job content, job restrictiveness, and repetitiveness (table 3). The work load cell classification (table 4 ), gave weight of materials $2(1-<5 \mathrm{~kg})$, cycle time $4(<5 \mathrm{~s})$, and degree of constrained neck postures 2 (high).

(2) Trimming of cod fillets. The last bones in the cod fillet were removed manually. This work task was performed either sitting or standing, with very short cycles. Also, trimming of cod involved frequent (about 100 times a day) handling of fish boxes (weighing about $22 \mathrm{~kg}$, not in table). In the ergonomic workplace analysis the task scored high figures for work postures and movements and repetitiveness. The work load cell classification gave weight of materials $1 \quad(<1 \mathrm{~kg})$, cycle time 3 $(5-<10 \mathrm{~s})$, and degree of constrained neck postures 3 (very high).

(3) Work at herring filleting machines implied turning the herring. These were automatically mounted in the machine, but were often incorrectly positioned. The herring

Table 3 Work environment assessments on six different work tasks in 13 different fish processing industries (medians (ranges) for ergonomic workplace analysis for the observed work tasks)

\begin{tabular}{|c|c|c|c|c|c|c|}
\hline \multirow[b]{2}{*}{ Ergonomic workplace analysis item } & \multicolumn{6}{|c|}{ Work task $(n=122)$} \\
\hline & $\begin{array}{l}\text { Cod machine } \\
(n=16)\end{array}$ & $\begin{array}{l}\text { Trimming of } \\
\operatorname{cod}(n=10)\end{array}$ & $\begin{array}{l}\text { Herring } \\
\text { machine } \\
(n=42)\end{array}$ & $\begin{array}{l}\text { Packing } \\
(n=17)\end{array}$ & $\begin{array}{l}\text { Supply, } \\
\text { removal } \\
(n=36)\end{array}$ & $\begin{array}{l}\text { Maintenance } \\
(n=21)\end{array}$ \\
\hline Work site $(\operatorname{good}=1, \mathrm{bad}=4)$ & $3(3-4)$ & $3(2-3)$ & $3(3)$ & $3(2-4)$ & $3(3-4)$ & $3(1-3)$ \\
\hline General physical activity (light $=1$, heavy $=4$ ) & $4(3-4)$ & $3(2-3)$ & $3(2-3)$ & $3(2-4)$ & $4(3-4)$ & $2(2-3)$ \\
\hline Lifting $($ no $=1,>21 \mathrm{~kg}=5)$ & $2(2-3)$ & $4(2-4)$ & $1(1)$ & $2(2-4)$ & $5(3-5)$ & $1(1-2)$ \\
\hline Work postures and movements (free $=1$, poor and fast $=5$ ) & $5(4-5)$ & $5(4-5)$ & $5(4-5)$ & $4(3-5)$ & $4(3-5)$ & $3(2-4)$ \\
\hline Job content (high $=1$, simple task $=5$ ) & $5(4-5)$ & $3(3-5)$ & $5(5)$ & $4(2-5)$ & $3(2-5)$ & $2(1-3)$ \\
\hline Job restrictiveness $($ none $=1$, complete $=5)$ & $5(4-5)$ & $4(3-5)$ & $5(4-5)$ & $4(2-5)$ & $3(2-5)$ & $3(2-3)$ \\
\hline Worker communication (very good $=1$, isolated $=5$ ) & $3(3-4)$ & $2(2-3)$ & $4(3-4)$ & $3(2-4)$ & $3(2-4)$ & $2(2)$ \\
\hline Difficulty of decision making ( simple $=1$, complicated $=5$ ) & $1(1-2)$ & $2(2-3)$ & $2(1-2)$ & $1(1-2)$ & $2(1-3)$ & $4(2-4)$ \\
\hline Repetitiveness $(>30 \min =1,<30 \mathrm{~s}=5)$ & $5(5)$ & $5(5)$ & $5(5)$ & $5(3-5)$ & $4(3-5)$ & $3(2-4)$ \\
\hline Attentiveness (superficial $=1$, very great $=4$ ) & $3(3)$ & $4(3-4)$ & $3(2-3)$ & $2(1-3)$ & $2(1-3)$ & $4(2-4)$ \\
\hline
\end{tabular}


Table 4 Assessed work load cells for the six most common work tasks in the 13 different fish processing industries (for packing and maintenance work, different work tasks classified within the group received different scores)

\begin{tabular}{|c|c|c|c|c|c|c|}
\hline \multirow[b]{2}{*}{ Work load cell } & \multicolumn{6}{|c|}{ Work task $(n=122)$} \\
\hline & $\begin{array}{l}\text { Cod machine } \\
(n=16)\end{array}$ & $\begin{array}{l}\text { Trimming of } \\
\operatorname{cod}(n=10)\end{array}$ & $\begin{array}{l}\text { Herring } \\
\text { machine } \\
(n=42)\end{array}$ & $\begin{array}{l}\text { Packing } \\
(n=17)\end{array}$ & $\begin{array}{l}\text { Supply, } \\
\text { removal } \\
(n=36)\end{array}$ & $\begin{array}{l}\text { Maintenance } \\
(n=21)\end{array}$ \\
\hline Materials weight $(<1 \mathrm{~kg}=1,>25 \mathrm{~kg}=5)$ & 2 & 1 & 1 & $1^{\star}, 3+$ & 5 & $2 \ddagger, 15$ \\
\hline Cycle time $(\geqslant 60 s=1,<5 s=4)$ & 4 & 3 & 4 & $4^{\star}, 2 \dagger$ & 2 & $2 \ddagger, 1 \S$ \\
\hline Neck constraint (low $=1$, very high $=3$ ) & 2 & 3 & 3 & $2 \star, 1 \dagger$ & 1 & $1 \neq, 1 \S$ \\
\hline
\end{tabular}

^Packing into small packages $(<1 \mathrm{~kg})$.

$\dagger$ Packing into larger packages.

$\neq$ Cleaning of fish boxes.

§Truck driving and repairs.

Table 5 Proportion of the total working time spent performing each of the six most common work tasks by men and women

\begin{tabular}{|c|c|c|c|c|c|c|c|c|}
\hline \multirow[b]{2}{*}{ Sex } & \multirow[b]{2}{*}{$n$} & \multicolumn{6}{|l|}{ Work task } & \multirow[b]{2}{*}{$\begin{array}{l}\text { Total } \\
(\%)\end{array}$} \\
\hline & & $\begin{array}{l}\text { Cod machine } \\
(\%)\end{array}$ & $\begin{array}{l}\text { Trimming } \\
\text { of } \operatorname{cod}(\%)\end{array}$ & $\begin{array}{l}\text { Herring } \\
\text { machine } \\
(\%)\end{array}$ & $\begin{array}{l}\text { Packing } \\
(\%)\end{array}$ & $\begin{array}{l}\text { Supply, } \\
\text { removal } \\
(\%)\end{array}$ & $\begin{array}{l}\text { Maintenance } \\
(\%)\end{array}$ & \\
\hline Men & 116 & 15 & 1 & 1 & 11 & 34 & 36 & 98 \\
\hline Women & 206 & 3 & 32 & 11 & 39 & 6 & 6 & 97 \\
\hline
\end{tabular}

constantly moved in front of the employee, thereby requiring continuous attention. The work was performed standing, with very short cycles ( $3 \mathrm{~s}$, not in table). Again work postures and movements, job content, job restrictiveness and repetitiveness, received maximal ergonomic workplace analysis scores. The task was classified in the work load cell weight of materials $1(<1 \mathrm{~kg})$, cycle time $4(<5 \mathrm{~s})$, and degree of constrained neck postures 3 (very high).

(4) Different types of packing. The cod and herring fillets were then packed in small or larger packages, which included varying durations of work cycles, all giving maximum ergonomic workplace analysis scores for repetitiveness. For packing into small packages $(<1 \mathrm{~kg})$, the work load cell classification gave weight of materials $1(<1 \mathrm{~kg})$, cycle time $4(<5 \mathrm{~s})$, and degree of constrained neck postures 2 (high). Packing into larger packages received material weight $3(5-<10 \mathrm{~kg})$, cycle time $2(10-<60 \mathrm{~s})$, and degree of constrained neck postures 1 (low).

Thus, all these four work tasks were repetitive, performed in constrained postures, with fast and continuous wrist and hand movements, mostly with a flexed neck, and with arms raised and lowered intermittently. The work was partly paid by the amount of work done.

(5) Supply and removal of bulk fish, often included handling of heavy weights $(40 \mathrm{~kg}$, not in table). This work task was performed standing and walking, and was partly paid according to the amount of fish filleted by the workers performing these tasks. The cycle times for lifting were mostly around 1 minute. The ergonomic workplace analysis rated five points for lifting and four points for repetitiveness. The task was rated in the work load cell weight of materials $5(>25 \mathrm{~kg})$, cycle time $2(10-<60$ s) and degree of constrained neck postures 1 (low).

(6) Maintenance work, which comprised more varied work tasks - for example, cleaning the fish boxes, repairs, and driving lorries. In the ergonomic workplace analysis these tasks did not score 5 points for any item. Instead they scored 4 points for difficulty of decision making and attentiveness. For cleaning the fish boxes, the work load cell denoted was weight of materials $2(1-<5 \mathrm{~kg})$, cycle time $2(10-<60 \mathrm{~s})$, and degree of neck constraint 1 (low), whereas lorry driving and repair work scored weight of materials $1(<1 \mathrm{~kg})$, cycle time $1(\geqslant 60 \mathrm{~s})$, and degree of neck constraint 1 (low).

Also, all work tasks scored four points in several of the ergonomic workplace analysis variables, implying non-satisfactory working conditions (table 3).

WORK ENVIRONMENT FACTORS VERSUS SEX A systematic evaluation showed a significant sex difference for the work tasks performed (table 5). Thus, for the women, the most common work tasks were trimming of cod, packing, and work at the herring filleting machine, and covered $82 \%$ of the total working time. For men, the three work tasks cod filleting machine, supply, and removal of bulk fish, and maintenance work covered $85 \%$ of the time.

The ergonomic workplace analysis (table 3) showed that all typical female work tasks received scores that indicated bad working conditions especially for repetitivity and working postures. However, for the male work tasks, ergonomic workplace analysis showed large differences in ratings - for example, between maintenance work and cod filleting there were differences in job content, decision making, and repetitiveness.

\section{Exposure profiles}

In the three dimensional figure, most of the working time of the men was found at the two extremes. Thus, the exposure profile for men showed that one quarter $(26 \%)$ of the total working time involved work with low physical exposure, performing mobile work with no or very light materials to handle. As much as 34\% of the time was spent in lifting $>25 \mathrm{~kg}$. This 


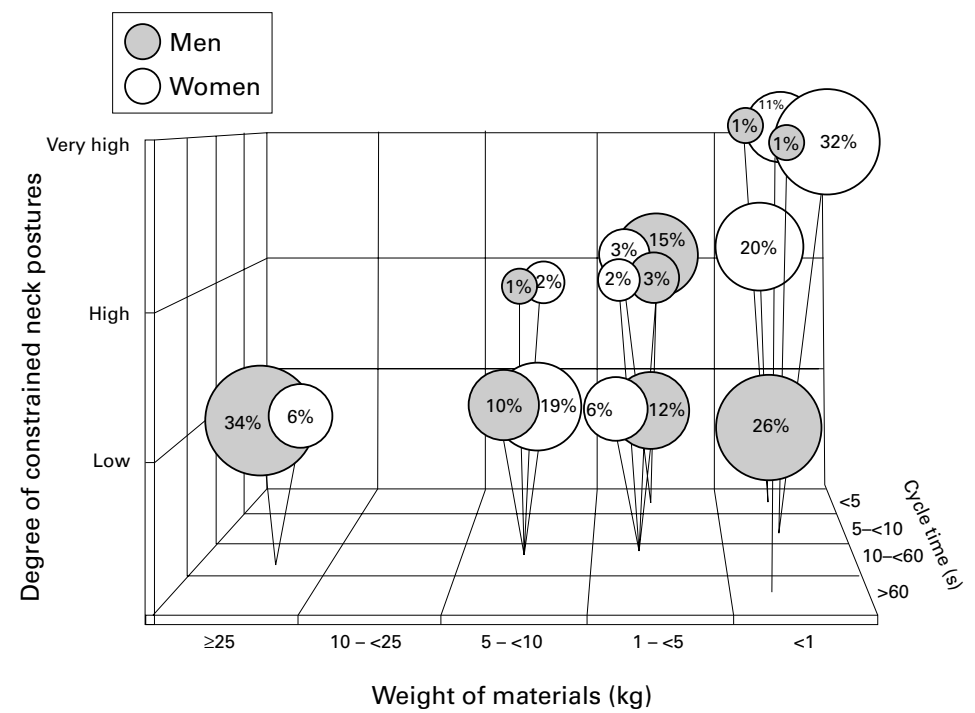

Male and female exposure profiles. Percentage of all working time performed in each work load cell, by each sex group. One hundred and sixteen men performed 17 different work tasks and 206 women performed 10 different work tasks, in 13 different fish processing factories.

involved lifting fish boxes. Several men handled a total daily weight of $10000-15000 \mathrm{~kg}$. As little as $2 \%$ was spent with a very high degree of constrained neck postures, as much as $15 \%$ with a high degree of constrained neck postures, handling weights of $1-5 \mathrm{~kg}$ with cycle time $<5 \mathrm{~s}$ (the cod filleting machine).

On the other hand, a very large fraction of the working time of the women $(63 \%)$ was spent with a high or a very high degree of constrained neck postures, handling materials weighing $<1 \mathrm{~kg}$, and with work cycles $<10 \mathrm{~s}$ (figure). Materials weighing $\geqslant 5 \mathrm{~kg}$ were handled for $25 \%$ of the total working time, performed with somewhat longer cycles (10-60 s), and less neck constraint (certain types of packing, with a total materials handling of 2000-6000 kg and day). Six per cent of the women's total working time was spent handling weights $>25 \mathrm{~kg}$. The women's exposure profile did not contain any work involving work cycles longer than $60 \mathrm{~s}$, handling materials weighing $<1 \mathrm{~kg}$, with a low degree of constrained neck postures.

Psychosocial work environment

Among the fish processing workers, the women had a much poorer psychosocial work environ- ment for all items, except relations with fellow workers, than the men (table 6). Further, their social network at work was less favourable.

Among the subjects with other work, the women, compared with the men, reported better relations with the supervisor, but less control, and a higher work strain, but the social network at work did not differ significantly.

Subjects in the fish processing industry showed a much poorer psychosocial work environment, than the other workers.

INDIVIDUAL FACTORS

The fish processing workers reported higher tendencies towards muscular tension as well as stress and worry than the subjects with other work (table 6). The women of both groups had a higher tendency to perceive muscular tension and stress and worry, than the men. The social network outside work did not differ between any of the groups.

Smoking was twice as common among the women in fish processing plants than among the women with other work (table 7). Among men no difference was recorded. In a multivariate analysis smoking showed no independent effect on the PORs, when simultaneously considering age and work exposure (not in table).

Handicrafts were almost exclusively performed by women, slightly more commonly among the fish processing workers than among the others (table 7). House and car repairs or gardening were common leisure time activities in all four groups, most common among men with mobile work. Half as many of the women fish processing workers practised sports as the other workers. Hunting or fishing was mostly performed by men, in both occupational groups. None of the leisure time activities showed an independent effect on the PORs (not in table).

\section{REASONS FOR LEAVING THE FISH PROCESSING} INDUSTRY

One quarter of the women who had left the fish processing plants, claimed to have done so because of musculoskeletal complaints (occurring before leaving the fish industry) in the neck or upper limbs, twice as often as did the men (table 8). The difference was most obvious for older women, in particular those who had been employed for $>2$ years (not in table).

Table 6 Psychosocial work environment factors and individual factors in 116 male and 206 female workers in the fish processing industry, as well as in 129 male and 208 female workers with other work (medians and p values from the Mann-Whitney U test)

\begin{tabular}{|c|c|c|c|c|c|c|c|}
\hline \multirow[b]{2}{*}{ Factor } & \multicolumn{3}{|c|}{ Fish processing } & \multicolumn{3}{|c|}{ Other work } & \multirow{2}{*}{$\begin{array}{l}\text { Fish processing v } \\
\text { other work }\end{array}$} \\
\hline & Men & Women & $p$ Value & Men & Women & $p$ Value & \\
\hline \multicolumn{8}{|l|}{ Psychosocial work environment ( $1=$ low, $5=$ high): } \\
\hline Control & 3.2 & 3.2 & $0.02^{\star}$ & 4.0 & 4.0 & $0.01^{\star}$ & $<0.001$ \\
\hline Climate & 4.0 & 3.4 & $<0.001$ & 3.8 & 4.0 & 0.03 & $<0.001$ \\
\hline Stimulation & 3.2 & 2.6 & $<0.001$ & 4.2 & 4.2 & $0.2 \dagger$ & $<0.001$ \\
\hline Fellowship & 4.2 & 4.2 & $0.3 \dagger$ & 4.6 & 4.4 & 0.5 & $<0.001$ \\
\hline Work strain & 3.4 & 3.2 & 0.002 & 4.0 & 3.4 & $<0.001$ & $<0.001$ \\
\hline \multicolumn{8}{|l|}{ Social network ( $1=$ seldom, $5=$ often $)$ : } \\
\hline During work & 4.0 & 3.6 & $<0.001$ & 4.4 & 4.3 & 0.13 & $<0.001$ \\
\hline Outside work & 2.8 & 2.8 & 0.8 & 3.0 & 2.8 & 0.09 & 0.6 \\
\hline Muscular tension ( $1=$ low, $11=$ very high $)$ & 1.0 & 3.0 & $<0.001$ & 1.0 & 2.0 & $<0.001$ & 0.008 \\
\hline Stress or worry during work ( $1=$ low, $5=$ high $)$ & 1.8 & 2.2 & 0.01 & 1.8 & 2.0 & 0.07 & 0.01 \\
\hline
\end{tabular}

*Women worse than men.

tMen worse than women. 
Table 7 Prevalence of daily smoking and leisure time activities among 116 male and 206 female workers in the fish processing industry, as well as among 129 male and 208 female workers with other work

\begin{tabular}{llllll}
\hline & \multicolumn{2}{l}{ Fish processing } & & \multicolumn{2}{l}{ Other work } \\
\cline { 2 - 3 } \cline { 6 - 6 } Factor & Men n (\%) & Women n (\%) & & Men n (\%) & Women n (\%) \\
\hline Smoking & $36(31)$ & $107(52)$ & & $40(31)$ & $47(23)$ \\
Handicraft & $1(1)$ & $102(50)$ & & $1(1)$ & $84(40)$ \\
Repairs & $71(61)$ & $116(56)$ & & $90(70)$ & $106(51)$ \\
Sports & $36(31)$ & $34(17)$ & & $38(30)$ & $69(33)$ \\
Fishing or hunting & $34(29)$ & $8(4)$ & & $32(25)$ & $5(2)$ \\
\hline
\end{tabular}

Table 8 Reason for leaving the fish processing industry among former workers

\begin{tabular}{llccc}
\hline Region & Age & $\begin{array}{l}\text { Men }(n=196) \\
n(\%)\end{array}$ & $\begin{array}{l}\text { Women }(n=322) \\
n(\%)\end{array}$ & p Value \\
\hline Neck or upper limb & $<45$ & $15(10)$ & $42(18)$ & 0.04 \\
& $>45$ & $8(19)$ & $36(44)$ & 0.01 \\
\multirow{3}{*}{ Other } & Total & $23(12)$ & $78(24)$ & $<0.001$ \\
& $<45$ & $19(12)$ & $8(3)$ & $<0.001$ \\
& $>45$ & $5(12)$ & $2(2)$ & 0.05 \\
& Total & $24(12)$ & $10(3)$ & $<0.001$
\end{tabular}

A case is defined as a person who reported pain in the neck or upper limb or in other anatomical regions (low back, hips, knees, and feet) as the main reason for leaving employment. p Value by Fisher's exact test.

Pain from other body regions-lower back, hips, knees, and feet-was reported by the men, more often than the women, as the main reason for leaving. For the men, this reason for leaving was just as common as complaints of the neck and upper limbs.

\section{Discussion}

The female fish processing industry workers had much higher prevalences of neck, shoulder, elbow, and hand disorders than the male workers, and considerably higher than the women with other work. A high risk of neck and upper limb disorders due to fish processing work has already been shown. ${ }^{26}$ Similarly, in the groups with other work, the women had higher prevalences of neck and shoulder disorders than the men. Further, among the former workers, the proportion who reported pain in the neck and upper limbs as the reason for leaving the fish processing industry was high, and it was clearly higher among women than among men. The true difference in incidence is presumably even larger. The underestimate is liable to be more prominent for the older women with longer durations of employment. There was no difference between the sexes for complaints in low back and lower limbs.

An unhealthy worker selection into the group of men with other work would give lower PORs for the men. It is, however, unlikely that this would be a major explanation of the discrepancy.

One problem when interpreting the results is a possible observation bias on the registration of disorders; it was, for obvious reasons, not possible to blind the sex and exposure status of the subjects. However, the physical examinations and interviews were performed by different people; both were fully aware of the potential bias. The possibility of an examiners' bias has been minimised, by a careful calibration between the examiners and by a systematic physical examination. Thus, we think that the bias is small, if present.
In the fish processing industries, men and women worked under equally bad conditions, as far as temperature, noise, and lighting were concerned. Due to food hygiene demands the fish was iced and the temperature in the factories was kept low. Melted ice and fish remnants created a slippery floor. A fish odour added to an unpleasant working environment. However, although the fishing industry is sex integrated-that is, does not contain $>70 \%$ of either $\operatorname{sex}^{27}$-the work tasks were strongly segregated. Despite the same job title, an exposure measure most often used in this type of study, the women did not share the same work tasks as the men. Presumably because of their lower muscle strength, the women had been assigned the seemingly less heavy work tasks. Also, probably mainly because of tradition, they had the least technical work tasks. The women were mostly assigned extremely repetitive work tasks which also, because of demands on sight, required very constrained neck postures. Most of the work tasks of the men were less repetitive and more mobile, although some of them were very heavy.

Great efforts have been made to classify the subjects into different exposure categories. However, due to frequent rotation between work tasks this is not possible. Consequently, the subjects cannot be assigned individual exposure doses, which can be related to outcome. As the work tasks and work organisation has not changed for many years, the same applies to the former workers.

Besides implying a physical work load, the repetitive work tasks entail a poor psychosocial work environment, in terms of low influence on and control over work combined with a lack of stimulus from the work itself. Thus, the women in the fish processing industry experienced a poorer psychosocial work environment than the men. On the other hand, in socioeconomically similar groups in other work, the women in some respects had a better psychosocial work environment than the men. This conglomerate of high physical exposure and a high psychosocial exposure is probably the primary cause for the difference in prevalence of disorders, between sexes within the fish processing industry as well as between the fish processing industry workers and the other workers. Unfortunately, as these two aspects of the work environment are so tightly entangled, it is not possible to estimate their separate impact on musculoskeletal disorders in this kind of work.

The men were exposed to heavier lifting and handling of materials than the women. Thus, many men lifted heavy burdens of fish (10 000-15 $000 \mathrm{~kg}$ daily). However, despite this, they did not report a high prevalence of low back complaints. This was probably, at least partly, due to a healthy worker selection out of the work. Also, there is a possibility that there had been a primary selection into the factories. Many men performed work tasks that were just as repetitive as those of the womenfor example, work at the cod machine. However, due to alternation between work tasks, the impact of this work load on the musculoskeletal system could not be shown. 
Women with other work had higher prevalence of neck and shoulder complaints than the corresponding men. On the other hand, the men reported more complaints in the low back and knees. This is in accordance with other studies. ${ }^{28}$

This study shows the advantage of a physical examination compared with a questionnaire. Hence, between the two groups of men studied, there was no difference in complaints on the questionnaire, whereas the physical examination showed large differences in morbidity. In our opinion, this mirrors a difference in severity of disorders. Another possibility is that the people all experience their grade of symptoms relative to the severity of disorders among their workmates. If everybody around you complains of pain, you might underplay your own disorders. Also, a "Tarzan" effect, implying cultural inhibitions by sex; men being less likely to complain, could explain the difference. This might also be true when comparing different ethnic groups. The prevalences of complaints were small, especially for the elbow and hand, which may undermine the true effects.

The same questionnaire has been evaluated against the same physical examination in an earlier study. ${ }^{16}$ It was concluded that the questionnaire gave a fairly good picture of musculoskeletal disorders in the neck and upper limbs in a population of working women. The physical examination, however, gave more details, and information about the severity of the problem. The same questionnaire has also been evaluated in a population of working men. ${ }^{29}$ The results indicated that the prevalence, as well as the risk, of musculoskeletal disorders might be underestimated when only a questionnaire is used.

The prevalence of carpal tunnel syndrome was low, compared with other studies. ${ }^{30}$ We think that this is due to the very strict criteria applied when deciding the diagnoses.

The women in the fish processing industry smoked more and practised sports less than any other group. These conditions had, however, no influence on the PORs of musculoskeletal disorders when comparing workers from the fish processing industry with other workers.

A study of sick leave ${ }^{31}$ showed a higher prevalence for fish industry workers than for the general population, and higher for women than for men. Complaints of the musculoskeletal system dominated. In subjects who had left their work, sick leave decreased.

As has often been recommended, most of the employees performed more than one task during the working day. However, for the women, the physical exposure in different tasks was very similar and offered no relief to the neck and upper limb structures. The existing tasks with different exposures seemed to be only available to the men. Accordingly, maintenance work was performed almost exclusively by the men. The work tasks included in that group did not receive high ergonomic workplace analysis scores for physical exposure; instead they had a high score for difficulty of decision making. This suggests a physical and mental load different from the typical work tasks of women. To include periods of maintenance work in the working schedule for all the workers would probably introduce a true variation of work load.

These results suggest the need for several actions in the working environment of the fish industry. The heavy work tasks of the men should be made easier, to make them suitable for women. Also, women should be stimulated to achieve technical competence and technical courage. This would make it possible to change the work to involve both women and men in all work tasks, which would enhance the quality of the psychosocial work environment and reduce the musculoskeletal disorders particularly among the women, but probably also among the men.

The study was supported by grants from the Swedish Council for Planning and Co-ordination of Research, the Swedish Work Environment Fund, the Committee for Social Research, and the Medical Faculty, Lund University. Valuable assistance with statistical analyses was given by Dr Ulf Strömberg. Skilful technical assistance was given by Ms Lothy Granqvist.

1 Nachemson AL. Spinal disorder. Overall impact on society and the need for orthopaedic resources. Acta Orthop Scand 1991;62:17-22.

2 Hagberg M, Wegman DH. Prevalence rates and odds ratios of shoulder-neck disease in different occupational groups. Br F Ind Med 1987;44:602-10.

3 Dimberg L, Olafsson A, Stefansson E, et al. The correlation between work environment and the occurrence of cervicobrachial symptoms. F Occup Med 1989;31:447-53.

4 Ohlsson K, Attewell R, Skerfving S. Self-reported symptoms in the neck and upper limbs of female assembly workers. in the neck and upper limbs of female assem

5 Ohlsson K, Balogh I, Hansson G-Â, et al. Neck and upper limb disorders in females in the fish processing industry. Occup Environ Health 1994;51:826-32.

6 Ohlsson K, Attewell RG, Pålsson B, et al. Neck and upper imb disorders in females with repetitive industrial work Am F Ind Med 1995;27:731-47.

7 Riihimäki H, Wickström G, Hänninen K, et al. Predictors of sciatic pain among concrete reinforcement workers and house painters: a five-year follow-up. Scand $\mathcal{f}$ Environ Health 1989;15:415-23.

8 Holmström EB, Lindell J, Moritz U. Low back pain and neck/shoulder pain in construction workers; occupational workload and psychosocial risk factors. Part 2: Relationship to neck and shoulder pain. Spine 1992;17:672-7.

9 Stock SR. Workplace ergonomics factors and the development of musculoskeletal disorders of the neck and upper
ment ment of musculoskeletal disorders of the neck and upper
limbs: a meta-analysis. Am f Ind Med 1991;19:87-107.

10 Mergler D, Brabant C, Vezina N, et al. The weaker sex? Men in women's working conditions report similar health symptoms. F Occup Med 1987;28:417-21.

11 Hagberg M. Exposure variables in ergonomic epidemiology. Am F Ind Med 1992;21:91-100.

12 Winkel J, Westgaard RH. Occupational and individual risk factors for shoulder-neck complaints: Part II - The scientific basis (literature review) for the guide. Int $\mathcal{F}$ Ind Erg 1992;10:85-104

13 Bigos SJ, Battié MC, Spengler DM, et al. A prospective study of work perceptions and psychosocial factors affecting the report of back injury. Spine 1991;1:1-6.

14 Bongers PM, de Winter CR, Kompier MAJ, et al. Psychosocial factors at work and musculoskeletal disease. Scand $\mathcal{F}$ Work Environ Health 1993;19:297-312.

15 Kuorinka I, Jonsson B, Kilbom A, et al. Standardised Nordic questionnaire for the analysis of musculoskeletal sympquestionnaire for the analysis of musculo
toms. Applied Ergonomics 1987;18:233-7.

16 Ohlsson K, Attewell RG, Alm A, et al. Assessment of neck/ upper extremity disorders by questionnaire and clinical upper extremity disorders by questionn

17 Rubenowitz S. Organisational psychology and leadership. Göteborg Esselte Studium, 1984:88-95. (In Swedish.)

18 Ahonen M, Launis M, Kuorinka T. Ergonomic workplace analysis. Helsinki: Finnish Institute of Occupational Health, 1989

19 Rohmert W, Landau K. AET: das Arbeitswissenschaftliche Erhebungsverfahren zur Tätigkeitsanalyse. Handbuch. Bern: Huber, 1979.

20 National Institute for Occupational Safety and Health. A work practices guide for manual lifting. Cincinatti, OH: US Department of Health and Human Services (NIOSH), 1981. (Technichal Report No 81-122.)

21 Theorell T, Harms-Ringdahl K, Ahlborg-Hultén G, et al. Psychosocial job factors and symptoms from the locomotor system - a multicausal analysis. Scand f Rehabil Med 1991; 23:65-173.

22 Johnsson JV. The impact of workplace social support, job demands and work control upon cardiovascular disease in 
Sweden [thesis]. Baltimore, Maryland: Johns Hopkins University, 1986:204

23 Freeman J, Hutchison GB. Prevalence, incidence, and duration. Am Ұ Epidemiol 1980;112:707-23.

24 Alho JM. On prevalence, incidence, and duration in general stable populations. Biometrics 1992;48:587-92.

25 Strömberg U. Prevalence odds ratio $v$ prevalence ratio: some further comments. Occup Environ Med 1995;52:143.

26 Chiang HC, Ko YC, Chen SS, et al. Prevalence of shoulder and upper-limb disorders among workers in the fishprocessing industry. Scand F Work Environ Health 1993;19: $126-31$.

27 Hall EM. Gender, work control, and stress: a theoretical discussion and an empirical test. Int $\mathcal{F}$ Health Serv 1989;19: $725-45$.
28 National Board of Occupational Safety and Health, Statistics Sweden. Occupational diseases and occupational accidents 1991. Stockholm: National Board of Occupational Safety and Health, Statistics Sweden, 1993.

29 Hagberg M, Johansson K, Jorulf L, et al. Is it possible to detect common diseases with a questionnaire? Hygiea 1989;98:123. (In Swedish).

30 Armstrong TJ, Buckle P, Fine LJ, et al. A conceptual model for work-related neck and upper-limb musculoskeletal disorders. Scand F Work Environ Health 1993;19:73-84.

31 Pålsson B, Strömberg U, Ohlsson K, et al. Absence attributed to incapacity and occupational disease/accidents among female and male workers in the fish-processing industry. Occup Med 1998;48:289-95.

\section{Correspondence and editorials}

Occupational and Environmental Medicine welcomes correspondence relating to any of the material appearing in the journal. Results from preliminary or small scale studies may also be published in the correspondence column if this seems appropriate. Letters should be not more than 500 words in length and contain a minimum of references. Tables and figures should be kept to an absolute minimum. Letters are accepted on the understanding that they be subject to editorial revision and shortening.

The journal also publishes editorials which are normally specially commissioned. The Editor welcomes suggestions regarding suitable topics; those wishing to submit an editorial, however, should do so only after discussion with the Editor. 